OPEN ACCESS

Edited by:

Marlen Ines Vasquez,

Cyprus University of Technology,

Cyprus

Reviewed by:

Adrianna lanora,

Anton Dohrn Zoological Station, Italy

Giovanna Romano,

Anton Dohrn Zoological Station, Italy

*Correspondence:

Cátia Gonçalves

cv.goncalves@campus.fct.unl.pt

Pedro M. Costa

pmcosta@fct.unl.pt

Specialty section:

This article was submitted to

Marine Biotechnology,

a section of the journal

Frontiers in Marine Science

Received: 29 December 2020

Accepted: 15 February 2021

Published: 26 February 2021

Citation:

Gonçalves $C$ and Costa PM (2021) Cephalotoxins: A Hotspot

for Marine Bioprospecting?

Front. Mar. Sci. 8:647344.

doi: 10.3389/fmars.2021.647344

\section{Cephalotoxins: A Hotspot for Marine Bioprospecting?}

\author{
Cátia Gonçalves* and Pedro M. Costa* \\ UCIBIO - Applied Molecular Biosciences Unit, Departamento de Ciências da Vida, Faculdade de Ciências e Tecnologia, \\ Universidade Nova de Lisboa, Almada, Portugal
}

Molluscs provided one of the pioneering approved pharmaceuticals from the seas: the painkiller ziconotide, developed from an $\omega$-conotoxin isolated from cone snails. As marine biotechnologists are turning towards the immense range of novel bioproducts from marine invertebrates, little attention has been given to cephalotoxins, a group of obscure proteinaceous toxins produced by the salivary glands of coleoids, i.e., octopuses, squids and cuttlefishes. These toxins, for which there is empirical evidence for acting as immobilisers at least against crustaceans, are proteinaceous substances among the many that comprise the venomous mixtures secreted by these animals. Despite the ecological and economical importance of cephalopods, little is known about cephalotoxins, beginning with the actual span of taxa that secrete them. Indeed, cephalopods are long suspected for producing specific toxins as part of their predation and defence mechanisms, making them a promising group of marine animals for the bioprospecting of novel compounds. Despite scant or absent toxicological or otherwise experimental evidence for their bioreactivity, advances in "omics" methods have shed some light in the molecular structure of cephalotoxins. There are reports of cephalotoxins being complex glycoproteins that take part in a myriad of novel compounds being produced by the salivary glands. Still, there is no consensus of cephalotoxins being a conserved form of proteins. As Blue Biotechnology and marine bioprospecting for novel bioreactives are gaining momentum, the present review will provide the state-of-the-art on cephalotoxins, highlighting old and new research and existing gaps in the current knowledge.

\section{Keywords: marine biotechnology, marine toxins, cephalopods, bioprospection, novel bioproducts, omics}

\section{INTRODUCTION}

Marine toxins are likely as diversified as the oceans' immense biodiversity and result from coevolutionary processes between the organisms that secrete them and their target recipients, whether prey, predators or parasites. Along with other types of natural products, these substances are considered to hold high-value bioproducts due to their potential specificity against molecular receptors and metabolic pathways. Many toxins from animals are peptides or high molecular weight proteins that interact with specific enzymes and ion channels (e.g., sodium and/or potassium ion channels), thus affecting, for example, neuromuscular, cardiovascular and immune systems (Zhang, 2015; Ponte and Modica, 2017). For these reasons, toxinology has been rising as a promising field with direct implications for drug discovery, novel therapeutic alternatives and even ecologically 
friendly antifoulants and pesticides. Although still lagging behind research on their terrestrial counterparts, such as snakes, bees and scorpions, marine toxinology is on the rise as researchers and bio-based industrialists become increasingly aware for the uncanny value of the oceans as an almost limitless source of novel bioproducts (see for instance Molinski et al., 2009; Leal et al., 2020).

Venoms are complex mixtures of toxins, enzymes, peptides and salts, which renders molecule isolation, identification and determination of substance-specific bioreactivity challenging. Their efficacy results from the interaction of these compounds, not just from toxins as noxious agents but also from permeabilisers like proteolytic enzymes. Still, several venomous or poisonous species of snakes, lizards, and leeches have already been used to produce toxin-based drugs for clinical applications directed against disease-induced pain (e.g., from osteoarthritis and multiple sclerosis), as anticoagulants for specific coronary interventions and also for hypertension or specific types of diabetes (see Bordon et al., 2020 for a review). Additionally, studies on wasp venoms are revealing promising alternatives for traditional antibiotics and even as antiviral and anti-seizure therapeutics (Vila-Farrés et al., 2012; Sample et al., 2013; Castro e Silva et al., 2020). In turn, pushed by the recent premises of the "Blue Growth" revolution, the last decade witnessed a growing interest in marine bioproducts, toxins included. Indeed, marine ecosystems are nowadays acknowledged to be a highly valuable source of pharmaceutically active toxins (see Greener, 2020). Notwithstanding, marine invertebrates are considered the most promising group of animals possessing toxins in face of their richness. Marine animals such cnidarians (jellyfishes, sea anemones, hydrozoans), echinoderms (starfishes, sea urchins), annelids (polychaetes), nemertines, bryozoans (moss animals), sponges, tunicates and molluscs (gastropods, cephalopods) stand out as toxin-secreting eumetazoans (see Kem, 2005; Zhang, 2015; Rodrigo and Costa, 2019). As examples, recent investigations highlighted bryostatins, which are heterocyclic molecules produced by bryozoans, and other cyclic peptides produced by endosymbiotic micro-organisms from some tunicates, as high-potential compounds for cancer therapeutics (Kem, 2005; Watters, 2018). As yet another example, clinical trials on toxic peptides from sun anemone have been revealed favourable results for the treatment of autoimmune diseases, due to their effects as strong potassium channel blockers (Prentis et al., 2018). However, the most prominent example among biotechnological applications of marine bioproducts is the approved painkiller ziconotide (commercialised as Prialt), developed from a $\omega$-conotoxin found in the venom of the cone snail Conus magus (Williams et al., 2008). This case has recently been followed by trabectedin (Yondelis), an anti-cancer quinoline first isolated from a tropical tunicate (Cuevas and Francesch, 2009), which, albeit not primarily a toxin, yields leverage to drug development from marine bioproducts.

As more species of marine invertebrates join the ranks of toxin-secreting marine animals, attention is turning to one of the oldest-known venomous group of molluscs, the cephalopods. Perhaps surprisingly, only a few toxins have yet been described for these predators but the broad range of bioactive compounds in their venomous saliva, which includes neurotoxic proteins and peptides, amines and permeabilising enzymes, yields high promises for marine bioprospecting (see Cooke et al., 2017). Recent advances in marine "venomics" (see von Reumont et al., 2014) can shed new lights on these obscure toxins. Cephalotoxins, in particular, appear to be a unique class of toxins whose exact nature remains elusive even though their discovery dates from the mid-XX century. In this review we will summarise the scant knowledge on these toxins that are produced by the salivary glands of cephalopods, endeavouring a fresh biotechnological perspective for the bioactives secreted by these important and ubiquitous animals.

\section{CEPHALOTOXINS AND OTHER COLEOID TOXINS}

The interest on cephalotoxins, albeit when they were not termed as such, rose in the late XIX century when Lo Bianco (1888) studied the toxicity of octopus saliva to crabs. These observations showed that after injecting secretions from octopus' posterior salivary glands directly into crab gills, the target experienced hindered locomotion, progressing rapidly towards complete immobilisation and eventually death (see also Ghiretti, 1960). The active substance that causes this paralysing action was latter purified by Ghiretti (1959) from the posterior salivary glands of Sepia officinalis, identified as a proteinaceous compound and called cephalotoxin. From that time onwards, the composition of salivary secretions of cephalopods gained attention and several constituents have since been isolated and identified, with emphasis on neurotoxins and neuropeptides (Table 1). It is now clear that the complexity of these secretions is reflected in a broad range of biologically active compounds, proteinaceous or not. This includes biological amines, namely tyramine, histamine, $p$-hydroxyphenyl-ethanolamine (octopamine), 5-hydroxytryptamine (5-HT or serotonin), noradrenaline or dopamine (Henze, 1913; Bottazzi and Valentini, 1924; Erspamer, 1948; von Euler, 1952; Erspamer and Asero, 1953; Hartman et al., 1960). Several enzymes have also been identified in cephalopod saliva, such as hyaluronidase, chitinase, phospholipase A2, peptidase S1, metalloprotease, carboxypeptidase (Romanini, 1952; Fry et al., 2009; Cornet et al., 2014; Whitelaw et al., 2016), as well as tachykinins (Eledoisin, OctTK-I, and OctTK-II) and CAP domain- (CRISP [Cysteinerich secretory proteins], Antigen 5 [Ag5], and Pathogenesisrelated [PR-1]) -bearing proteins (Erspamer and Anastasi, 1962; Kanda et al., 2003; Fry et al., 2009). However, the number of cephalopod species covered in terms of its toxin identification is still acknowledged to be very low (Cooke et al., 2017). From both Superorders of Class Cephalopoda, Octopodiformes accounts for the highest number of investigated species (about 14 from a total of 300). As for Decapodiformes, i.e., cuttlefishes and squids, not even $2 \%$ of all known species have been studied for the characterisation of salivary gland secretions. The number of species for which there is detailed information on cephalotoxins is even smaller. The octopuses Octopus vulgaris, Hapalochlaena maculosa, and Eledone cirrhosa, were the first to have $\alpha$ - 
TABLE 1 | A comparative overview cephalotoxins and other major proteinaceous or peptidic neurotoxins considered specific of cephalopods.

\begin{tabular}{|c|c|c|c|c|c|c|}
\hline Species & Toxin name & $\begin{array}{c}\text { Molecular } \\
\text { weight (kDa) }\end{array}$ & $\begin{array}{l}\text { Isoelectric } \\
\text { point }\end{array}$ & $\begin{array}{l}\text { Known mode-of-action/ } \\
\text { Bioreactivity }\end{array}$ & $\begin{array}{l}\text { Post- } \\
\text { translational } \\
\text { modifications }\end{array}$ & References \\
\hline $\begin{array}{l}\text { Doryteuthis } \\
\text { (Amerigo) pealeii }\end{array}$ & $\begin{array}{l}\text { Unknown cytolytic } \\
\text { protein }\end{array}$ & - & - & - & - & $\begin{array}{l}\text { Kem and Scott, } \\
1980\end{array}$ \\
\hline Eledone cirrhosa & Eledone toxin & $30-70$ & $>7$ & Neurotoxin & - & $\begin{array}{l}\text { McDonald and } \\
\text { Cottrell, } 1972\end{array}$ \\
\hline $\begin{array}{l}\text { Eledone moschata } \\
\text { Eledone cirrhosa }{ }^{\mathrm{b}}\end{array}$ & Eledoisin ${ }^{c}$ & - & - & Hypotensive agent & - & $\begin{array}{l}\text { Erspamer and } \\
\text { Anastasi, } 1962\end{array}$ \\
\hline $\begin{array}{l}\text { Enteroctopus } \\
\text { dofleinid }\end{array}$ & - & 22.15 & $5.2-5.3$ & Potential neurotoxin & - & $\begin{array}{l}\text { Songdahl and } \\
\text { Shapiro, } 1974\end{array}$ \\
\hline Octopus vulgaris & $\alpha$-cephalotoxin & 91.20 & $4.5-5.1$ & $\begin{array}{l}\text { Neurotoxin (inhibitor of } \\
\text { glutamate-mediated synaptic } \\
\text { transmission) }\end{array}$ & - & $\begin{array}{l}\text { Cariello and Zanetti, } \\
1977\end{array}$ \\
\hline Octopus vulgaris & $\beta$-cephalotoxin & 33.90 & $1.8-2.5$ & $\begin{array}{l}\text { Neurotoxin (inhibitor of } \\
\text { glutamate-mediated synaptic } \\
\text { transmission) }\end{array}$ & - & $\begin{array}{l}\text { Cariello and Zanetti, } \\
1977\end{array}$ \\
\hline Octopus vulgaris & $\begin{array}{l}\text { OctTK-I and } \\
\text { OctTK-II }\end{array}$ & - & - & Hypotensive agent & - & Kanda et al., 2003 \\
\hline Sepia esculenta & SE-Cephalotoxin ${ }^{\mathrm{e}}$ & 100 & 9.08 & Neurotoxin & Glycosylation & Ueda et al., 2008 \\
\hline Sepia officinalis & Cephalotoxin & - & - & Neurotoxin & - & Ghiretti, 1959 \\
\hline Sepia pharaonis & - & $\sim 50$ & - & Antibacterial agent & - & Karthik et al., 2015 \\
\hline Sepia prashadi & - & 1.96 & - & $\begin{array}{l}\text { Potential antibacterial and } \\
\text { antiviral agent }\end{array}$ & - & Karthik et al., 2019 \\
\hline
\end{tabular}

a Name updated from Loligo pealei.

${ }^{b}$ Name updated from Eledone aldrovandi.

c12-amino acid neuropeptide.

'Name updated from Octopus dofleini.

e UniProt accession B2DCR8.

[-] Data not available/unknown.

and $\beta$-cephalotoxin, hapalotoxin, and Eledone toxin identified, respectively (McDonald and Cottrell, 1972; Cariello and Zanetti, 1977; Savage and Howden, 1977). Indeed, Hapalochlaena spp. (the famous blue-ringed octopus) is particularly known for the potency of its neurotoxic agents, which are lethal and devoid of known antidote. Later, Sheumack et al. (1978) was able to identify tetrodotoxin (TTX) in the posterior salivary glands of the octopus Hapalochlaena maculosa as well. This non-peptidic neurotoxin is not, however, exclusive to octopus' salivary glands since it was found in multiple body parts of the animal, including arms, cephalothorax and abdomen (Yotsu-Yamashita et al., 2007). It must be noted, though, that TTX is a secondary metabolite best-known from pufferfishes (Tetraodontidae) as well as in other marine animals and amphibians, with its synthesis being associated to endosymbiotic bacteria (Lago et al., 2015). Despite the aforementioned studies, information on the bioreactivity and structural properties of cephalotoxins is still very limited. However, cephalotoxins from octopuses and Sepia esculenta have been conclusively identified as functional proteins. The latter species, in particular, yielded, to date, the only complete cephalotoxin amino acid sequence available from a curated record at UniProt, which illustrates how little is known about these substances whose existence is known for more than a century. Toxins from Sepia pharaonis and Sepia prashadi, and from the squid Doryteuthis (Amerigo) pealeii have also been identified as unknown cytotoxic proteins secreted by posterior salivary glands (Kem and Scott, 1980; and purified by Karthik et al. $(2015,2019)$, which may indicate potential cephalotoxin candidates.

\section{Secretion, Delivery, and Mode-of-Action}

As carnivores, cephalopods use envenomation as a means for hunting, however, it may also confer defence against predators (Chichery and Chichery, 1988; Norman and Reid, 2000). Naturally, the secretion of cephalotoxins by salivary glands and their delivery via a wound created by the typical parrot beak of coleoids indicates a major role in feeding. The salivary glands (anterior and posterior) are the constituents of the digestive system responsible for secreting substances that intervene directly in the capture of prey, as well as in lubricating and protecting the digestive tract, besides contributing to the predigestive process (see Fernández-Gago et al., 2018 and references therein for details). The anterior salivary glands of cephalopods are located behind the buccal mass and are compound tubuloacinar glands mostly composed by granular and mucous secretory cells (Fernández-Gago et al., 2018). However, the disposition of the posterior salivary glands, where active toxins are secreted, is more variable. While octopuses and cuttlefishes possess a pair of posterior salivary glands, squids have only a single gland (see for instance BoucaudCamou and Boucher-Rodoni, 1983). The posterior salivary glands are adjacent to the digestive gland and are tubular as well. In octopodids, granular and mucous cells are strongly present in glandular epithelia, the latter being responsible for 
the production of acidic glycoconjugate mucins (FernándezGago et al., 2018). In sepioids (cuttlefishes), the mucous cells of salivary glands secrete tryptophan-rich proteinaceous substances (Boucaud-Camou, 1968). Interestingly, enterochromaffin cells (a type of neuroendocrine cells) have been detected in the posterior salivary glands of octopods as well, albeit absent in sepioids (Boucaud-Camou and Boucher-Rodoni, 1983). In turn, salivary gland morphoanatomy for the Teuthoidea (squids) is scarce. In any case, the relationship between salivary gland structure, biochemistry and toxin secretion remains somewhat elusive.

The buccal mass plays a paramount role in toxin delivery. Here is located the posterior salivary gland duct, running within the salivary papilla, and the anterior salivary gland duct, both opening into the buccal cavity. During an attack, the toxic secretions produced by the posterior salivary glands are delivered to the prey through a wound created by quick bite rather than by injection through the two-piece beak (also called rostrum). Toxins with immobilising properties, with the aid of permeabilising enzymes plus cardioexcitatory and vasodilatory substances, are promptly disseminated through the prey's circulatory system, rapidly affecting mobility and motor coordination (Zhang, 2015; Lobo-da-Cunha, 2019). Likely, the copious amount of mucus comprising neutral glycoproteins, sialic acid, dipeptidase and hyaluronidase secreted by the anterior salivary glands, is the delivery vehicle of the bioactive compounds secreted by the posterior salivary glands (Budelmann et al., 1997; Ponte and Modica, 2017).

The number of detailed studies on the toxicological effects of cephalopod salivary secretions is still considerably low. Most bioassays were performed on decapod crustaceans and in general report the paralysing properties of crude secretions from a few species of octopuses, squids and cuttlefishes (Ghiretti, 1959; McDonald and Cottrell, 1972; Songdahl and Shapiro, 1974; Cariello and Zanetti, 1977; Savage and Howden, 1977;
Ueda et al., 2008; Cornet et al., 2014). However, there are some studies performed on mice that suggest toxicity to vertebrates as well (Ueda et al., 2008). Whenever the chemical nature of these secretions was investigated, cephalotoxins were consistently present and considered the compounds with highest toxic activity. Cephalotoxins seem to a have a powerful paralysing action against models as distinct as crustaceans and mice by blocking the electrical and mechanical responses of muscles (McDonald and Cottrell, 1972), even though the exact mechanisms are not known. Songdahl and Shapiro (1974) also stated that the speed of the toxicological reaction may be dose-dependent. Further, Ueda et al. (2008) demonstrated that distinct cephalopod species secrete toxins with different potencies against the same target species, i.e., whereas salivary extracts from cuttlefish were lethal to crabs and non-toxic to mice, extracts from squid revealed higher toxicity against mice. Cariello and Zanetti (1977) verified a similar toxicological reaction of the cephalotoxins upon octopus itself, causing significant lethality as well. Additionally, toxicological studies on strains of Gram-positive and Gram-negative bacteria confirmed that peptidic extracts of the Sepia officinalis posterior salivary glands revealed bactericidal and antimicrobial activities (Cornet et al., 2014). Disclosing allo- or orthosteric ligands for cephalotoxins in target organisms would provide a major leap in understanding mode-of-action of these toxins and eventually explore their biotechnological potential.

\section{Molecular Characterisation of Cephalotoxins}

Knowledge on the molecular structure of cephalotoxins is scant or incomplete. The most complete characterisation of these toxins, so far, was obtained by Ueda et al. (2008), who disclosed a full 1052-amino acid sequence for a cephalotoxin variant
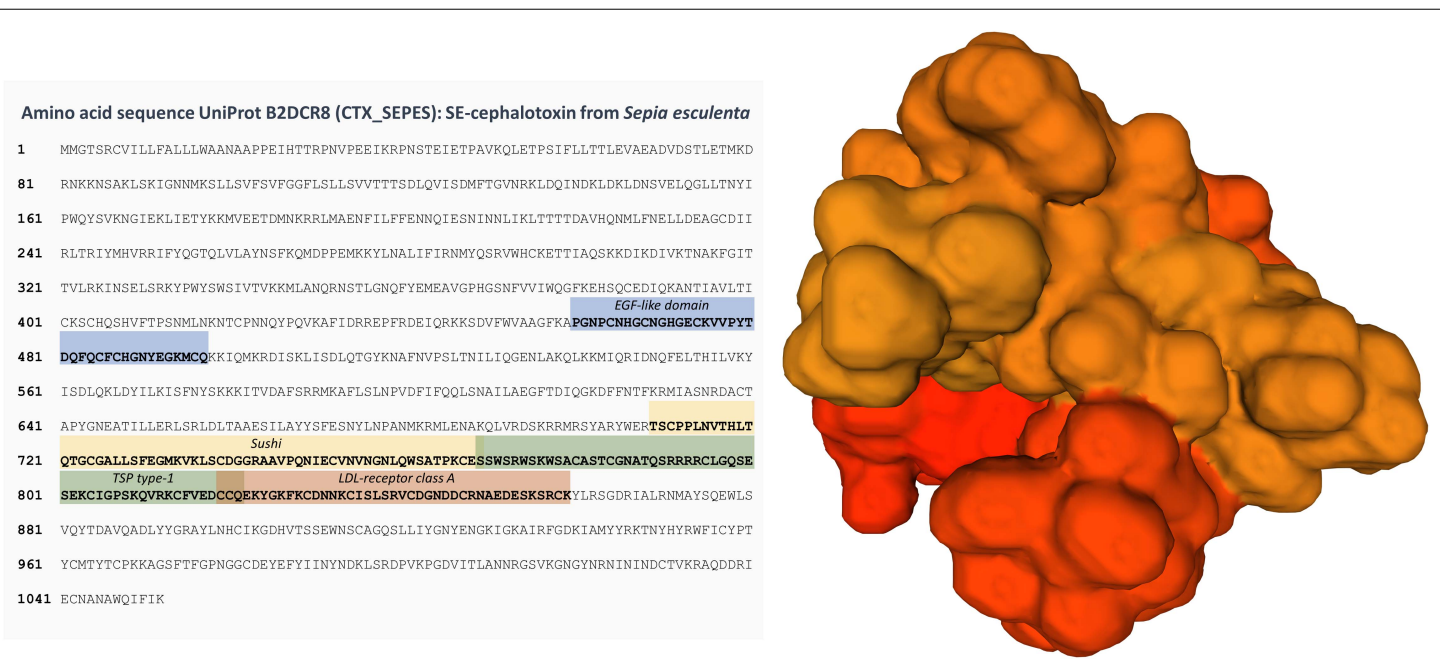

FIGURE 1 | Sequence and a predicted 3D model of SE-cephalotoxin. Conserved domains are highlighted in the sequence, namely EGF-like, Sushi, TSP type-1, and LDL-receptor class A. Molecule was produced with Swiss-Model from the UniProt record B2DCR8 (CTX_SEPES). Glycosylation is not represented. See Ueda et al. (2008) for further details. 
from the posterior salivary glands of the golden cuttlefish, Sepia esculenta. This form, termed SE-cephalotoxin by the same authors appears to be $\mathrm{a} \approx 100 \mathrm{kDa}$ monomeric protein whose amino acid sequence was determined from isolated cDNAs. The same authors also purified the protein by high-performance liquid chromatography (HPLC) and confirmed the findings by Western Blotting. Some of the most distinctive features of the protein is glycosylation at five distinct sites and the presence of four conserved domains, namely EGF-like, Sushi, TSP type-1 and LDL-receptor class A (Figure 1). Some of these, particularly the EFG- (epidermal growth factor) like domain have already been described in venom proteins such as in the gigantoxins from the cnidarian Stichodactyla gigantea, which interfere with sodium channels and have paralytic activities against crustaceans (Shiomi et al., 2003). Cephalotoxins may thus be considered as belonging to the class commonly referred to as EGF (neuro)toxins.

Despite the absence of further cephalotoxin mRNA or amino acid sequences from curated databases, cephalotoxin-like proteins (possibly non-toxic) have been found in a number of aquatic organisms, from fish to the exoskeleton of some corals (e.g., Ramos-Silva et al., 2013). However, the role and evolution of these proteins remains obscure. Still, important insights have been provided by Ruder et al. (2013), who used an RNA-Seq transcriptomic approach to study multiple toxins secreted by octopus, cuttlefish and squid, revealing for the first time the existence of cephalotoxin-like proteins in all these three major groups by homology matching.

\section{PROSPECTS FOR POTENTIAL BIOTECHNOLOGICAL APPLICATIONS}

As mentioned earlier, it is believed that the immobilising or paralysing activity of cephalotoxins against invertebrate prey, especially arthropods, can result from the interference with specific ion channels or receptors. On the very least, cephalotoxins could be explored for the development of natural and safer pesticides against arthropods (namely insecticides). Nonetheless, verified effects on murines open excellent prospects for biomedical applications, similarly to conotoxins and TTX, especially for the development of safer and non-addictive painkillers. In fact, Cariello and Zanetti (1977) reported cephalotoxins from $O$. vulgaris to be able to block glutamatemediated synaptic transmission, a signalling process involved precisely in pain sensation (see for instance Wozniak et al., 2012). Nonetheless, only few bioactives from the cephalopod salivary glands are indeed under scientific scrutiny for potential applications. Among such studies, research on extracts from Sepia pharaonis and Sepia prashadi posterior salivary glands revealed antimicrobial activity against avian bacterial pathogens and also a potential function as an anti-metastatic agent (Karthik et al., 2015, 2017, 2019). These findings suggest that, adding to neurotoxic effects, biocidal and anti-proliferative properties of cephalotoxins and other components of cephalopod venoms can point to novel antibiotics and anti-cancer drugs, further confirming the rising interest of cephalopod toxins for biotechnology. It must be noted that even TTX, albeit being ubiquitous among many animal taxa (cephalopods included) and one of the best-known and most lethal nonpeptidic neural ion channel blockers, has also been considered for the development of analgesic and anaesthetic drugs in advanced cancer patients (Hagen et al., 2007). Indeed, under the trade name Tectin, TTX is already in phase III trials for the treatment of pain resulting from chemotherapy treatments (Newman and Cragg, 2014). To these applications we may add the potential deployment of TTX in the treatment for opioid dependence and management of withdrawal symptoms, with has already started phase IIa clinical trials as Tetrodin (Butler, 2005; Shi et al., 2009; Song et al., 2011). Similarly, the TTX-based drug Tocudin, has also started preclinical studies as a formulation intended for local anaesthesia (Butler, 2005). These findings highlight the high prospects set upon potential applications of marine animal toxins. Proteinaceous toxins such as cephalotoxins and conotoxins may offer advantages over those derived from primary or secondary metabolites, as they can be safer, more easily eliminated (by proteolytic activity) and, very importantly, directly cloned into adequate vectors for heterologous expression. In the latter case, constraints posed by protein secretion and post-translational modifications, such as glycosylation, can be circumvented by choosing eukaryote models, like yeast.

\section{LESSONS LEARNED AND FUTURE PERSPECTIVES}

Even though the discovery and description of coleoid venomous secretions dates back to the XIX century, their toxins remain obscure. Cephalotoxins, albeit being consensually found to be the most bioreactive substances in the venom secreted by the posterior salivary gland of these animals (whereas the anterior gland provides the mucin-rich vehicle of delivery), are no exception. Their potent neurotoxic and potential cytotoxic effects, together with the proteinaceous nature, makes them particularly appealing for drug discovery. Such endeavour requires, nonetheless, more solid knowledge on their molecular structure and their interaction with target receptors. With this respect, "omics" approaches, particularly proteomics and transcriptomics, can greatly assist in the filling-in of proteins secreted by the salivary glands of cephalopods by screening multiple peptides and proteins in single runs. These approaches may therefore provide a scaffold to support downstream finer structural details of the substances. The "big picture" must also be complemented with finely tuned toxicity and bioreactivity testing to provide the comprehensive bottom-up perspective needed to devise effective applications.

\section{AUTHOR CONTRIBUTIONS}

CG and PC designed the conceptual framework of the manuscript. CG collected information and drafted the 
manuscript with important input and supervision from PC. Both authors contributed to the article and approved the submitted version.

\section{FUNDING}

The authors acknowledge "Fundo Azul" for the funding of research project MARVEN (Ref. FA_05_2017_007). The Applied Molecular Biosciences Unit (UCIBIO) was financed

\section{REFERENCES}

Bordon, K. C. F., Cologna, C. T., Fornari-Baldo, E. C., Pinheiro-Júnior, E. L., Cerni, F. A., Amorim, F. G., et al. (2020). From animal poisons and venoms to medicines: achievements, challenges and perspectives in drug discovery. Front. Pharmacol. 11:1132. doi: 10.3389/fphar.2020.01132

Bottazzi, F., and Valentini, V. (1924). Nuove ricerche sul veleno della "saliva" di Octopus macropus. Arch. Sci. Biol. 6, 153-168.

Boucaud-Camou, E. (1968). Etude histologique et histochimique de l'appareil digestif de Sepiola atlantica d'Orbigny et Sepia officinalis L. Bull. Soc. Linn. Normandie 9, 220-243.

Boucaud-Camou, E., and Boucher-Rodoni, R. (1983). "Feeding and digestion in cephalopods," in The Mollusca Physiology Part 2, Vol. 5, eds A. S. M. Saleuddin and K. M. Wilburk (New York, NY: Academic Press), 149-187. doi: 10.1016/ b978-0-12-751405-5.50011-7

Budelmann, B. U., Schipp, R., and von Boletzky, S. (1997). "Cephalopoda," in Microscopic Anatomy of Invertebrates Mollusca II, Vol. 6A, eds F. W. Harrison and A. J. Kohn (New York, NY: Wiley-Liss), 119-414.

Butler, M. S. (2005). Natural products to drugs: natural product derived compounds in clinical trials. Nat. Prod. Rep. 22, 162-195. doi: 10.1039/ b402985m

Cariello, L., and Zanetti, L. (1977). $\alpha$ - and $\beta$-cephalotoxin: two paralysing proteins from posterior salivary glands of Octopus vulgaris. Comp. Biochem. Physiol. 57, 169-173. doi: 10.1016/0306-4492(77)90066- 1

Castro e Silva, J., Lopes do Couto, L., de Oliveira Amaral, H., Gomes, F. M. M., Campos, G. A. A., Silva, L. P., et al. (2020). Neuropolybin: a new antiseizure peptide obtained from wasp venom. Biochem. Pharmacol. 181:114119. doi: 10.1016/j.bcp.2020.114119

Chichery, M. P., and Chichery, R. (1988). Manipulative motor activity of the cuttlefish Sepia officinalis during prey-capture. Behav. Process 17, 45-56. doi: 10.1016/0376-6357(88)90049-6

Cooke, I. R., Whitelaw, B., Norman, M., Caruana, N., and Strugnell, J. M. (2017). "Toxicity in cephalopods," in Evolution of Venomous Animals and Their Toxins. Toxinology, eds P. Gopalakrishnakone and A. Malhotra (Dordrecht: Springer), $125-143$.

Cornet, V., Henry, J., Corre, E., Le Corguille, G., Zanuttini, B., and ZatylnyGaudin, C. (2014). Dual role of the cuttlefish salivary proteome in defense and predation. J. Proteomics 108, 209-222. doi: 10.1016/j.jprot.2014. 05.019

Cuevas, C., and Francesch, A. (2009). Development of yondelis ${ }^{\circledR}$ (trabectedin, ET743). a semisynthetic process solves the supply problem. Nat. Prod. Rep. 26, 322-337. doi: 10.1039/b808331m

Erspamer, V. (1948). Active substances in the posterior salivary glands of octopoda. II. tyramine and octopamine (oxyoctopamine). Acta Pharmacol. Toxicol. 4:224. doi: 10.1111/j.1600-0773.1948.tb03345.x

Erspamer, V., and Anastasi, A. (1962). Structure and pharmacological actions of Eledoisin, the active endecapeptide of the posterior salivary glands of Eledone. Experientia 15, 58-59. doi: 10.1007/bf02138250

Erspamer, V., and Asero, B. (1953). Isolation of enteramine from extracts of posterior salivary glands of Octopus vulgaris and of Discoglossus pictus skin. J. Biol. Chem. 200, 311-318. doi: 10.1016/s0021-9258(18)3 8466-7 by national funds from the Portuguese Foundation for Science and Technology (FCT) (UIDP/04378/2020 and UIDB/04378/2020). FCT is also acknowledged for the Grant SFRH/BD/144914/2019 awarded to CG.

\section{ACKNOWLEDGMENTS}

We wish to thank the SeaTox Lab and MARVEN project teams for their support and encouragement.

Fernández-Gago, R., Molist, P., and Rocha, F. (2018). Anatomical and histochemical features of the digestive system of Octopus vulgaris Cuvier, 1797 with a special focus on secretory cells. Acta Zool. 100, 1-16.

Fry, B. G., Roelants, K., and Norman, J. A. (2009). Tentacles of venom: toxic protein convergence in the kingdom animalia. J. Mol. Evol. 68, 311-321. doi: 10.1007/s00239-009-9223-8

Ghiretti, F. (1959). Cephalotoxin: the crab-paralysing agent of the posterior salivary glands of cephalopods. Nature 183, 1192-1193. doi: 10.1038/1831192b0

Ghiretti, F. (1960). Toxicity of octopus saliva against crustacea. Ann. N. Y. Acad. Sci. 90, 726-741. doi: 10.1111/j.1749-6632.1960.tb26417.x

Greener, M. (2020). The next generation of venom-based drugs. Prescriber 31, 28-32. doi: 10.1002/psb.1837

Hagen, N. A., Fisher, K. M., Lapointe, B., du Souich, P., Chary, S., Moulin, D., et al. (2007). An open-label, multi-dose efficacy and safety study of intramuscular tetrodotoxin in patients with severe cancer-related pain. J. Pain Symptom Manage. 34, 171-182. doi: 10.1016/j.jpainsymman.2006.11.008

Hartman, W. J., Clark, W. G., Cyr, S. D., Jordon, A. L., and Leibhold, R. A. (1960). Pharmacologically active amines and their biogenesis in the octopus. Ann. N. Y. Acad. Sci. 17, 637-666. doi: 10.1111/j.1749-6632.1960.tb26411.x

Henze, M. (1913). p-Oxyphanylaethylamin, das speicheldrusengift der cephalopoden. Hoppe-Seylers Z. Physiol. Chem. 87, 51-58. doi: 10.1515/bchm2.1913.87.1.51

Kanda, A., Iwakoshi-Ukena, E., Takuwa-Kuroda, K., and Minakata, H. (2003). Isolation and characterization of novel tachykinins from the posterior salivary gland of the common octopus Octopus vulgaris. Peptides 24, 35-43. doi: 10. 1016/s0196-9781(02)00274-7

Karthik, R., Manigandan, V., Ebenezar, K. K., Kavitha, M., and Saravanan, R. (2019). Structural characterization, teratogenicity and in vitro avian antimicrobial activity of posterior salivary gland (PSG) toxin from cuttlefish, Sepia prashadi. Int. J. Biol. Macromol. 124, 1145-1155. doi: 10.1016/j.ijbiomac. 2018.12.040

Karthik, R., Manigandan, V., Ebenezar, K. K., Vijayashree, R., and Saravanan, R. (2017). In vitro and in vivo anticancer activity of posterior salivary gland toxin from the cuttlefish Sepia pharaonis, Ehrenberg (1831). Chem. Biol. Interact. 272, 10-20. doi: 10.1016/j.cbi.2017.04.002

Karthik, R., Saravanan, R., Ebenezar, K. K., and Sivamalai, T. (2015). Isolation, purification, and characterization of avian antimicrobial glycopeptide from the posterior salivary gland of Sepia pharaonis. Appl. Biochem. Biotechnol. 175, 1507-1518. doi: 10.1007/s12010-014-1370-8

Kem, W. R. (2005). "Marine organisms," in Encyclopedia of Toxicology, 2nd Edn, ed. P. Wexler (Cambridge, MA: Academic Press), 16-21. doi: 10.1017/ cbo9780511803567.003

Kem, W. R., and Scott, J. D. (1980). Partial purification and characterization of a cytotoxic protein from squid (Loligo pealei) posterior salivary glands. Biol. Bull. 158:475.

Lago, J., Rodríguez, L. P., Blanco, L., Vieites, J. M., and Cabado, A. G. (2015). Tetrodotoxin, an extremely potent marine neurotoxin: distribution, toxicity, origin and therapeutical uses. Mar. Drugs 13, 6384-6406. doi: 10.3390/ md13106384

Leal, M. N., Anaya-Rojas, J. M., Munro, M. H. G., Blunt, J. W., Melian, C. J., Calado, R., et al. (2020). Fifty years of capacity building in the search for new marine natural products. Proc. Natl. Acad. Sci. U. S. A. 117, 24165-24172. doi: $10.1073 /$ pnas.2007610117 
Lo Bianco, S. (1888). Notizie biologiche riguardanti specialmente il periodo di maturità sessuale degli animali del Golfo di Napoli. Mitth. Z. Stat. Neapel. 8:385.

Lobo-da-Cunha, A. (2019). Structure and function of the digestive system in molluscs. Cell Tissue Res. 377, 475-503. doi: 10.1007/s00441-019-03085-9

McDonald, N. M., and Cottrell, G. A. (1972). Purification and mode of action of toxin from Eledone cirrosa. Comp. Gen. Pharmacol. 3, 243-248. doi: 10.1016/ 0010-4035(72)90033-x

Molinski, T. F., Dalisay, D. S., Lievens, S. L., and Saludes, J. P. (2009). Drug development from marine natural products. Nat. Rev. Drug Discov. 8, 69-85. doi: $10.1038 / \mathrm{nrd} 2487$

Newman, D. J., and Cragg, G. M. (2014). Marine-sourced anti-cancer and cancer pain control agents in clinical and late preclinical development. Mar. Drugs 12, 255-278. doi: 10.3390/md12010255

Norman, N., and Reid, A. (2000). A Guide to Squid, Cuttlefish and Octopuses of Australasia. Clayton, Vic: CSIRO Publishing.

Ponte, G., and Modica, M. V. (2017). Salivary glands in predatory mollusks: evolutionary considerations. Front. Physiol. 8:580. doi: \url\{https://doi.org/10. 3389/fphys.2017.00580\}

Prentis, P. J., Pavasovic, A., and Norton, R. S. (2018). Sea anemones: quiet achievers in the field of peptide toxins. Toxins 10:36. doi: 10.3390/toxins10010036

Ramos-Silva, P., Kaandorp, J., Huisman, L., Marie, B., Zanella-Cléon, I., Guichard, N., et al. (2013). The skeletal proteome of the coral Acropora millepora: the evolution of calcification by co-option and domain shuffling. Mol. Biol. Evol. 30, 2099-2112. doi: 10.1093/molbev/mst109

Rodrigo, A. P., and Costa, P. M. (2019). The hidden biotechnological potential of marine invertebrates: the polychaeta case study. Environ. Res. 173, 270-280. doi: 10.1016/j.envres.2019.03.048

Romanini, M. G. (1952). Osservazioni sulla ialuronidasi delle ghiandole salivari enteriorie posteriori degli octopodi. Pubbl. Staz. Zool. Napo. 23, 251-270.

Ruder, T., Sunagar, K., Undheim, E. A. B., Ali, S. A., Wai, T., Low, D. H. W., et al. (2013). Molecular phylogeny and evolution of the proteins encoded by coleoid (cuttlefish, octopus, and squid) posterior venom glands. J. Mol. Evol. 76, 192-204. doi: 10.1007/s00239-013-9552-5

Sample, C. J., Hudak, K. E., Barefoot, B. E., Koci, M. D., Wanyonyi, M. S., Abraham, S., et al. (2013). A mastoparan-derived peptide has broad-spectrum antiviral activity against enveloped viruses. Peptides 48, 96-105. doi: 10.1016/j.peptides. 2013.07.014

Savage, I. V. E., and Howden, M. E. H. (1977). Hapalotoxin, a second lethal toxin from the octopus Hapalochlaena maculosa. Toxicon 15, 463-466. doi: 10.1016/0041-0101(77)90127-1

Sheumack, D. D., Howden, M. E. H., Spence, I., and Quinn, R. J. (1978). Maculotoxin: a neurotoxin from the venom glands of the octopus Hapalochlaena maculosa identified as tetrodotoxin. Science 199, 188-189.

Shi, J., Liu, T. T., Wang, X., Epstein, D. H., Zhao, L. Y., Zhang, X. L., et al. (2009). Tetrodotoxin reduces cue-induced drug craving and anxiety in abstinent heroin addicts. Pharmacol. Biochem. Behav. 92, 603-607.
Shiomi, K., Honma, T., Ide, M., Nagashima, Y., Ishida, M., and Chino, M. (2003). An epidermal growth factor-like toxin and two sodium channel toxins from the sea anemone Stichodactyla gigantea. Toxicon 41, 229-236.

Song, H., Li, J., Lu, C. L., Kang, L., Xie, L., Zhang, Y. Y., et al. (2011). Tetrodotoxin alleviates acute heroin withdrawal syndrome: a multicentre, randomized, double-blind, placebo-controlled study. Clin. Exp. Pharmacol. Physiol. 38, 510514.

Songdahl, J. H., and Shapiro, B. I. (1974). Purification and composition of a toxin from the posterior salivary gland of Octopus dofleini. Toxicon 12, $109-115$.

Ueda, A., Nagai, H., Ishida, M., Nagashima, Y., and Shiomi, K. (2008). Purification and molecular cloning of SE-cephalotoxin, a novel proteinaceous toxin from the posterior salivary gland of cuttlefish Sepia esculenta. Toxicon 52, 574-581.

Vila-Farrés, X., Giralt, E., and Vila, J. (2012). Update of peptides with antibacterial activity. Curr. Med. Chem. 19, 6188-6198.

von Euler, U. S. (1952). Presence of catechol amines in visceral organs of fish and invertebrates. Acta Physiol. Scand. 28, 297-305.

von Reumont, B. M., Campbell, L. I., and Jenner, R. A. (2014). Quo Vadis venomics? a roadmap to neglected venomous invertebrates. Toxins 6, 3488-3551.

Watters, D. J. (2018). Ascidian toxins with potential for drug development. Mar. Drugs 16:162.

Whitelaw, B. L., Strugnell, J. M., Faou, P., da Fonseca, R. R., Hall, N., Norman, M., et al. (2016). Combined transcriptomic and proteomic analysis of the posterior salivary gland from the southern blue-ringed octopus and the southern sand octopus. J. Proteome Res. 15, 3284-3297.

Williams, J. A., Day, M., and Heavner, J. E. (2008). Ziconotide: an update and review. Expert. Opin. Pharmacother. 9, 15751583.

Wozniak, K. M., Rojas, C., Wu, Y., and Slusher, B. S. (2012). The role of glutamate signaling in pain processes and its regulation by GCP II inhibition. Curr. Med. Chem. 19, 1323-1334.

Yotsu-Yamashita, M., Mebs, D., and Flachsenberger, W. (2007). Distribution of tetrodotoxin in the body of the blue-ringed octopus (Hapalochlaena maculosa). Toxicon 49, 410-412.

Zhang, Y. (2015). Why do we study animal toxins? Zool. Res. 36, 183-222.

Conflict of Interest: The authors declare that the research was conducted in the absence of any commercial or financial relationships that could be construed as a potential conflict of interest.

Copyright (C) 2021 Gonçalves and Costa. This is an open-access article distributed under the terms of the Creative Commons Attribution License (CC BY). The use, distribution or reproduction in other forums is permitted, provided the original author(s) and the copyright owner(s) are credited and that the original publication in this journal is cited, in accordance with accepted academic practice. No use, distribution or reproduction is permitted which does not comply with these terms. 